\title{
Performance of cement-stabilized weak subgrade for highway embankment construction in Southeast Nigeria
}

\author{
Chukwuka Ifediniru $^{1^{*}}$ (D) and Nnamdi E. Ekeocha ${ }^{2}$
}

\author{
*Correspondence: \\ chuksife@gmail.com \\ 1 Department of Geology, \\ Faculty of Science, University \\ of Port Harcourt, Choba, \\ Rivers State, Nigeria \\ Full list of author information \\ is available at the end of the \\ article
}

\begin{abstract}
Soils with poor shear strength and high compressibility underlie the wetlands of southern Nigeria. They are susceptible to intolerable settlements and account for greater than $60 \%$ of the soils in the region. While requiring embankments for any infrastructure construction, these weak soils pose significant threat to the construction and service life of highway pavements in southeastern Nigeria. Therefore, this research investigates shear strength improvement of a highway embankment's weak subgrade soil after mass stabilization of soil with 6 and $10 \%$ Portland cement. The factor of safety against shear failure of the embankment was analyzed for un-stabilized subgrade and then cement-stabilized subgrade. The analysis was carried out for embankment heights of 4 , 5,6 and $7 \mathrm{~m}$ using the limit equilibrium method. Thick soft clayey silt with $\mathrm{Cu}$ range of 9 to $15 \mathrm{kPa}$ underlay the embankment, upon improvement, the $\mathrm{Cu}$ of 154 and $208 \mathrm{kPa}$ was obtained for 6 and 10\% stabilization respectively. The FoS for the embankment on Un-stabilized soil ranged from 0.88 for a $7 \mathrm{~m}$ embankment to 1.2 for a $4 \mathrm{~m}$ embankment. The FoS after mass stabilization of 1 to $5 \mathrm{~m}$ soil ranged between 1.77 and 5.22 for the different embankment heights. Stability was better improved as depth of mass stabilization and cement content increased. A linear relationship was observed to exist between the cement content, strength of the improved soils, stabilization depth and the factor of safety.
\end{abstract}

Keywords: Embankment, Stability, Factor of safety, Cement, Shear strength, Stabilization

\section{Introduction}

The southern Nigeria landscape are low lands dissected with various streams and estuaries forming the delta of the Niger River. The presence of these streams and estuaries are accompanied by abundant deposits of weak organic soils. Weak expansive soils typically have low shear strength, high compressibility and great affinity for moisture to the effect that intolerable settlements result [10]. Occurrences and spread of weak problem soils in Nigeria has been documented by Abdulfatai et al. [1], Adesunloye [3], Chukwueze [9], Bolarinwa and Ola [6], Ekeocha and Akpokodje [15], Ola [30]. Civil infrasrtuctural constructions on these weak soils are prone to distress caused by their low shear strength accompanined with high compressibility characteristics [36]. Highway construction on

(c) The Author(s), 2021. Open Access This article is licensed under a Creative Commons Attribution 4.0 International License, which permits use, sharing, adaptation, distribution and reproduction in any medium or format, as long as you give appropriate credit to the original author(s) and the source, provide a link to the Creative Commons licence, and indicate if changes were made. The images or other third party material in this article are included in the article's Creative Commons licence, unless indicated otherwise in a credit line to the material. If material is not included in the article's Creative Commons licence and your intended use is not permitted by statutory regulation or exceeds the permitted use, you will need to obtain permission directly from the copyright holder. To view a copy of this licence, visit http:// creativecommons.org/licenses/by/4.0/. 
soft weak soils are usually preceded by the construction of embankments. Embankments on this weak soil usually undergo large deformations predominantly caused by poor construction practices and quick undrained loading of the weak subsoil during construction. Embankment on weak soil usually experiences large deformation from the onset of construction thereby generating safety concerns in the short term (during construction) [20].

During embankment construction, excess pore pressure develops, the inability of a weak subsoil to gain strength from dissipation of the generated pore pressure increase stress of the subgrade. The result is the onset of shear failure along a possible slip surface as shear resistance of the weak soil is exceeded. The factor of safety against shear failure then gives a measure of the safety requirement for the embankment [35]. The proposed factor of safety value for an embankment is usually set at a minimum value having considered impactful analysis factors such as

- Uncertainties in the study method used.

- Reliability of soil design parameters used in analysis.

- Economic and social consequences of failure.

Embankment safety is usually most critical at the construction stage. Specifications require that stability analysis should satisfy a short-term factor of safety of 1.3 while long term stability ought to satisfy a factor of safety of $1.5[5,13,19,38]$.

Several authors, for instance Omotosho and Eze-Uzomaka [31], Ekeocha and Akpokodje [15], Ofudu et al. [29], Etim et al. [17] etc. have studied the chemical improvement of weak soft soils using additive such as cement, lime, fly ash, bitumem etc. or their combinations. Cement however happens to be an attractive choice of binder partly due to its effevtiveness in improving soil strength, relatively low cost and readily availability [31]. Stabilization of subgrade with cement can be achieved using the ex-situ method or in-situ method [24]. Just as has been rightly researched and documented by Ingles and Metcalf [22], Sherwood [37], Euro SoilStab [18] and Makusa [24], improved strength, volume stabilized, compressibility, durability and permeability charactiristics of the soil are most desirable in chemical stabilization campagins.

This study; as a contribution, investigates the strength improvement of weak cohesive fluvial soil from southeast of Nigeria stabilized with $6 \%$ and $10 \%$ ordinary Portland cement by analyzing the factor of safety improvement of a highway embankment founded on weak soft soil subgrade, the objectives of this study did not include the determination of the optimum binder content for the soft soil. Mass mixing or deep stabilization [18], an in situ stabilization method where dry or wet slurry chemical binders are introduced to stabilize a determined voulme or depth of weak soil inplace has been considered in this study.

\section{Methodology}

\section{Location and site condition}

The highway embankment is located between Latitude $5.0788810-5.1503420^{\circ} \mathrm{N}$ and Longitude $8.505419-8.34854^{\circ} \mathrm{E}$ along a $20 \mathrm{~km}$ highway being constructed in Odukpani local government area, north-east of Calabar, Cross River, Nigeria (Fig. 1). Thick 

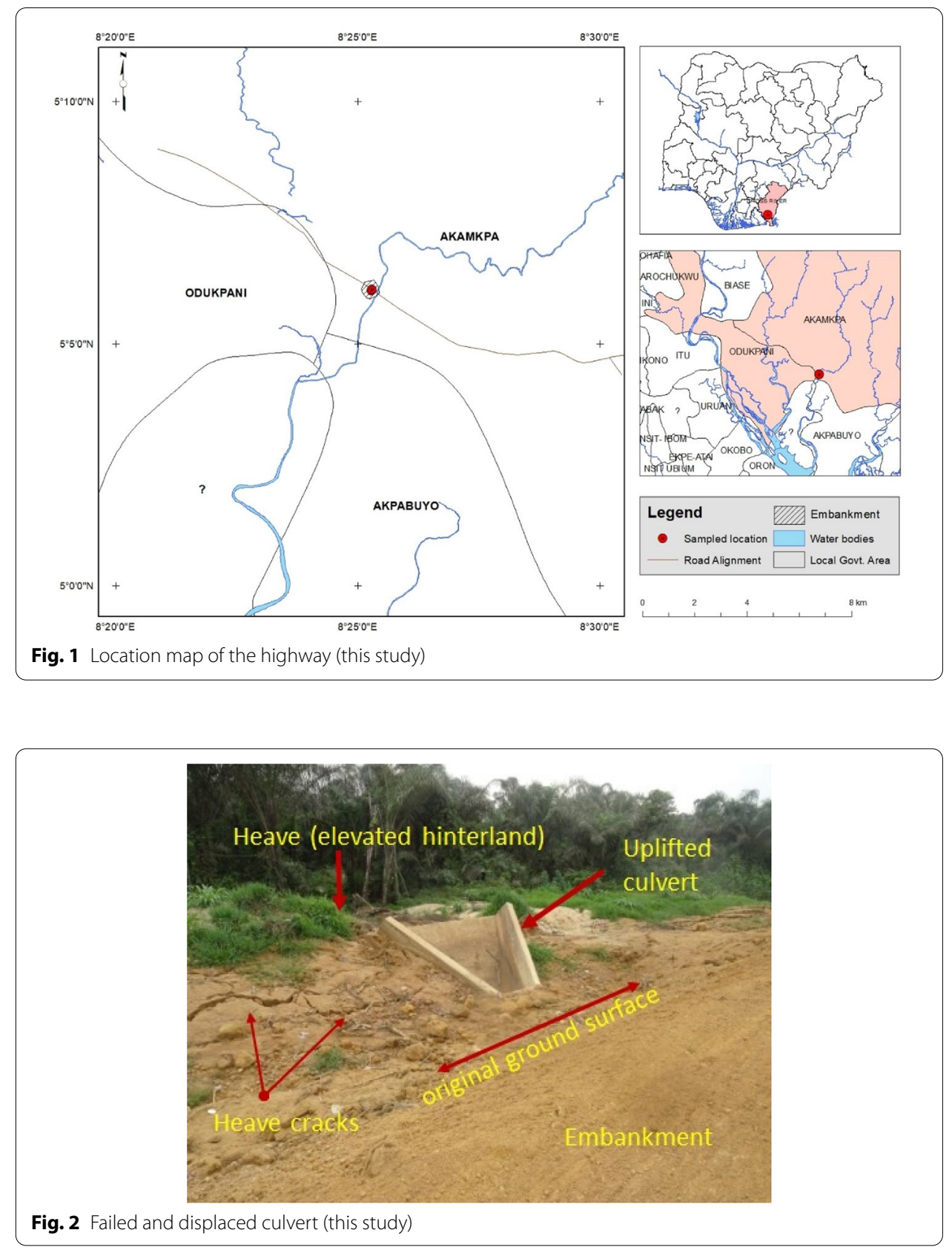

low strength soil underlies sections of the highway. The highway, which was currently under construction was experiencing several stages of embankment failure (Figs. 2, 3 and 4). The standing groundwater level at the site is between 0 and $0.5 \mathrm{~m}$, complete flooding of some road section occurs during extended rainfalls (Fig. 5). In the geological settings (Fig. 6), the area is located within the Calabar Flank sedimentary basin of Nigeria comprising of an ancient river-borne Sandstone known as the Awi Formation overlying an Albian to late Cretaceous marine Odukpani Group comprising of the Ekenkpong Shale and the New Netim marl capped by the Nkporo shale, marine shales and regressive sandstones of Tertiary origin overlie the Cretaceous formations $[2,16$, 

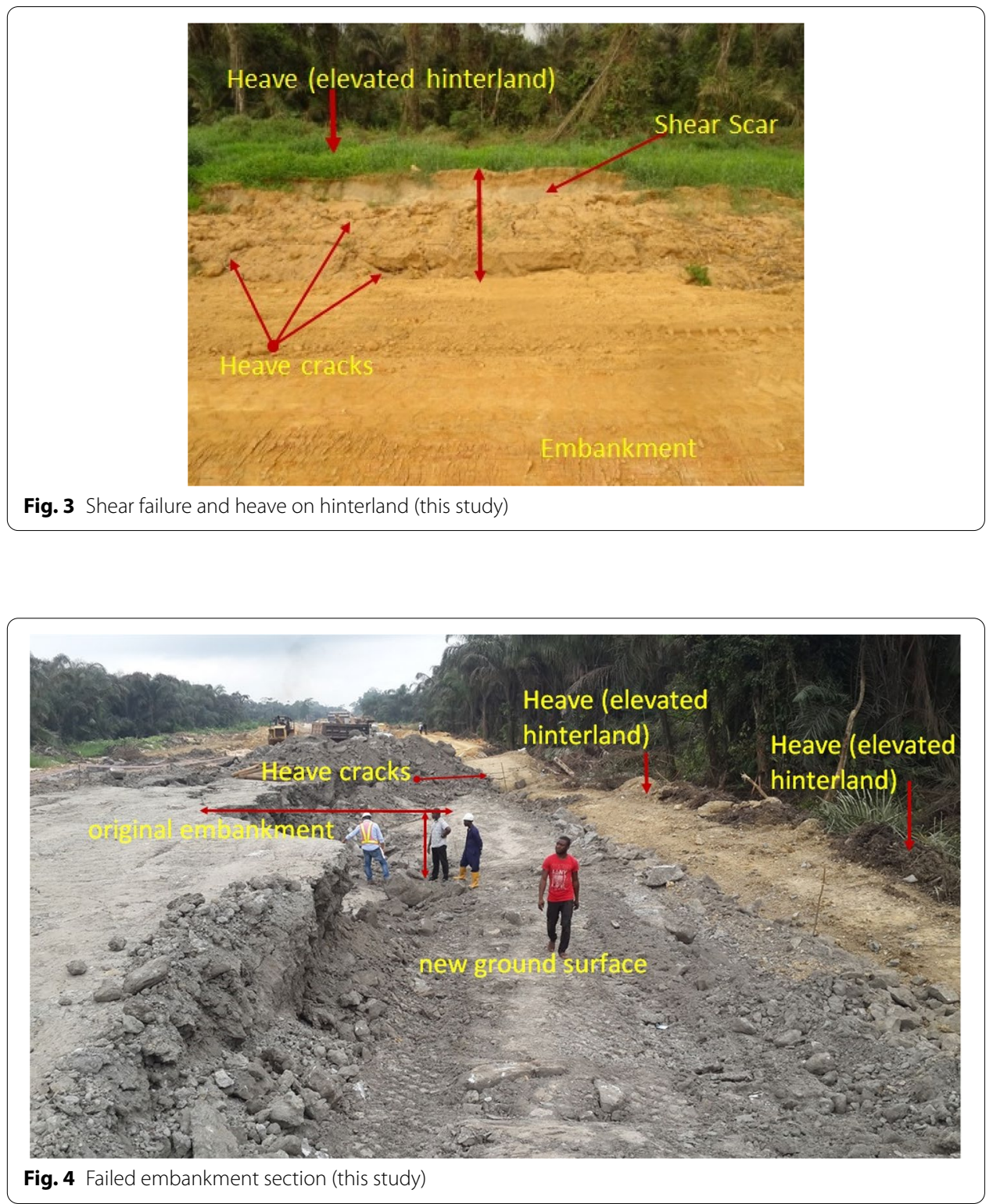

33, 34]. The Nkporo shale outcrop at the location and has been blasted to create route for the highway alignment.

\section{Materials and methods}

The assessment of the soil at the location included obtaining soil samples from geotechnical boreholes for classification and strength determination. The boreholes were drilled at the center and on the flanks of the embankment, samples were collected according to code of practice for site investigations (BS 5930:2015). Laboratory test were carried out on selected samples to obtain index and strength properties of both un-stabilized (USS) and cement stabilized soil (CSS). The strength characteristics of 


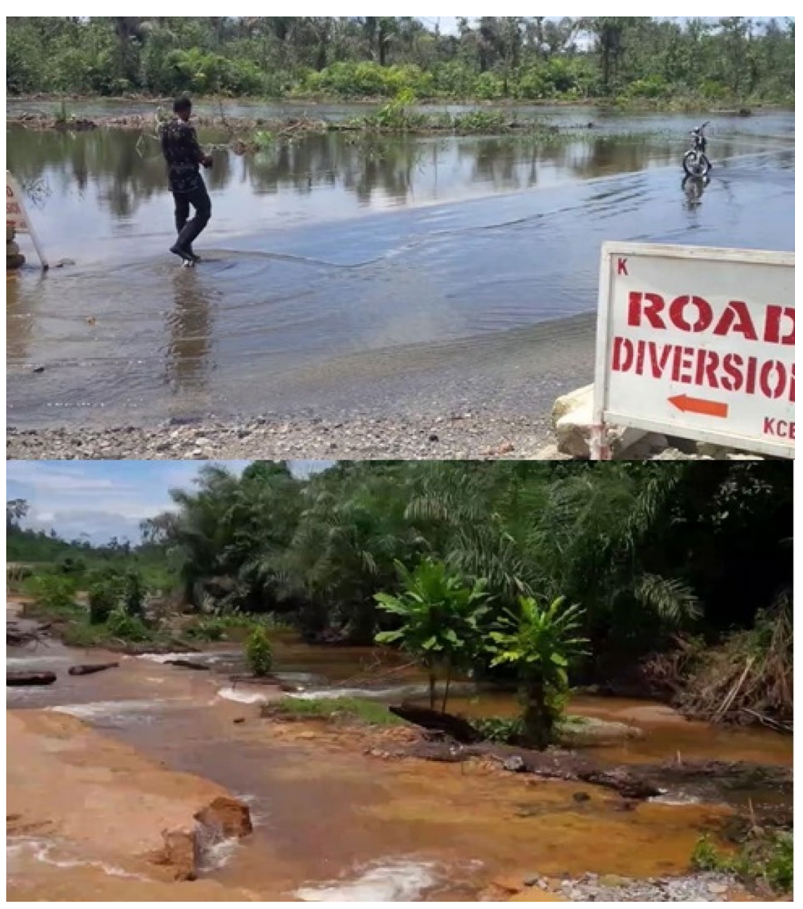

Fig. 5 Flooding of road section (this study)
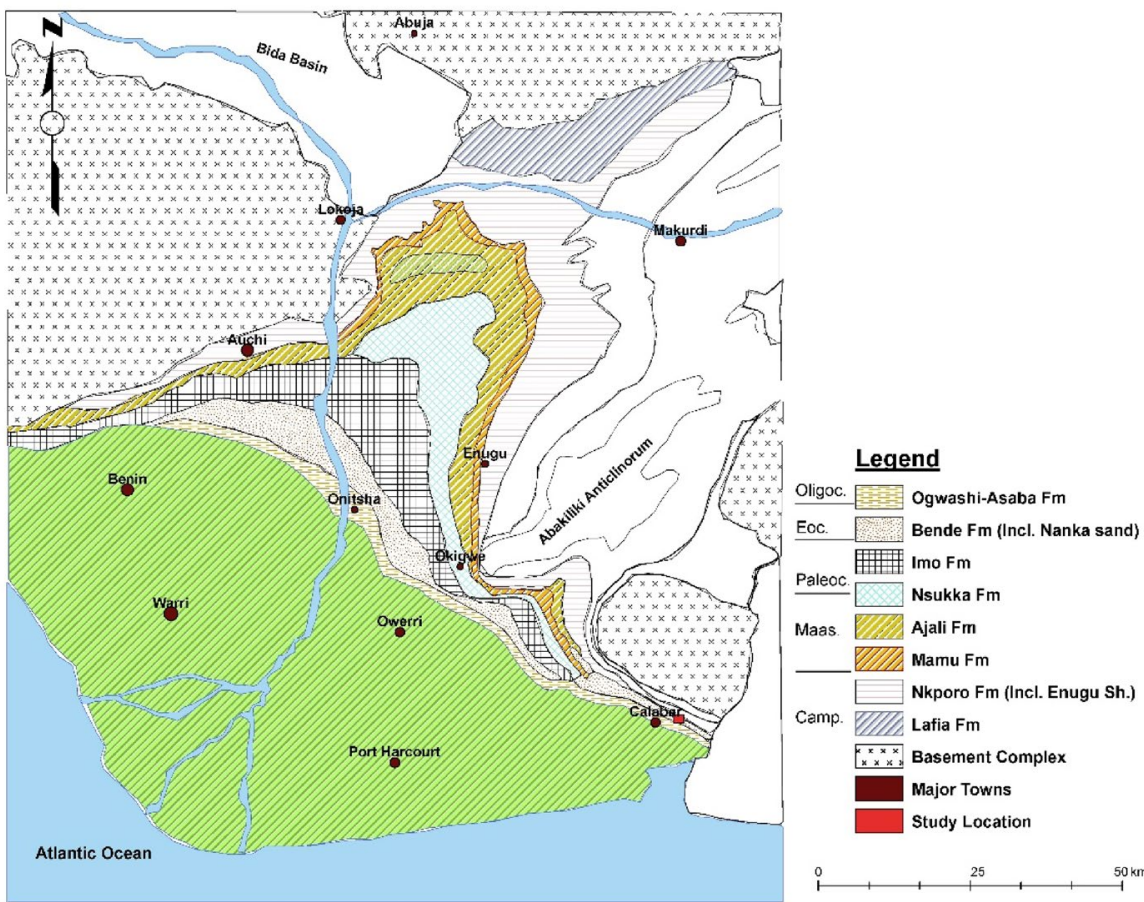

Fig. 6 Geologic map (after [28]) 
the weak soil were obtained from undrained triaxial tests while that of the CSS was determined from unconfined compressive strength tests [18].

To investigate the strength improvement, weak soil samples were improved with 6 and $10 \%$ cement quantity by weight. Approximately $8 \mathrm{~kg}$ of the soil sample and cement quantities were mixed at the soil's natural moisture content with a standard laboratory mixer for approximately $15 \mathrm{~min}$ to obtain a homogenous mix. The sample were then emptied into a mold in layers of $25 \mathrm{~mm}$ thickness and compacted with a steel stamp immediately after mixing, care was taken to avoid trapping of air or liquid bubbles. The mix in mould was allowed to cure for 28 days at a room temperature of $21^{\circ}$ to $25^{\circ} \mathrm{C}$ [18]. Since stabilized soil produced rock like samples after binding, UCS test was preferred for the stabilized soil as a quick and simple test providing basis for comparison between different binder quantities. UCS test was carried out on the cured sample after removal from mold at a constant strain rate until axial strain rate of $15 \%$ and brittle failure occurred.

\section{Chemical stabilization principle}

Cement is a widely used chemical stabilization agent which alters the chemical nature of the soil through a hydration process producing bonded soil mass or skeletal hardened soil [26], has capacity to achieve stabilization alone, is not dependent on soil mineral grains and will not alter the structure of the soil [18], with its reaction involving soil moisture being a key role in stabilization. The chemical components of cement which include tri-calcium silicate $\left(3 \mathrm{CaO} \cdot \mathrm{SiO}_{2}\right)$, di-calcium silicates $\left(2 \mathrm{CaO} \cdot \mathrm{SiO}_{2}\right)$, tri-calcium aluminate $\left(3 \mathrm{CaOAl} \mathrm{O}_{3}\right)$ and tetra-calcium alumino ferrite $\left(4 \mathrm{CaO} \cdot \mathrm{Al}_{2} \mathrm{O}_{3} \cdot \mathrm{Fe}_{2} \mathrm{O}_{3}\right)$ when in contact with chemical components of soil produces the cohesion and adhesion required to achieve stabilization [32]. Al-Tabbaa and Perera [4], Euro SoilStab [18], both identified calcium silicates, $C_{3} S$ and $C_{2} S$ as the principal cementitious component of Portland cement giving it the capacity for strength improvement. Calcium hydroxide, a hydration product of Portland cement, also produces cementitious properties when it combines with pozzolanic materials available in stabilized soils [37]. MacLaren and White [23] noted that cement hydration involves series of complex and relatively unknown chemical reaction, which affects the hydration process, however Makusa [24] suggested a range of factors which include presence of impurities, the water to cement ratio, the curing temperature, inclusions of additives and the specific surface of the cement-soil mixture will influence both the setting time of the mix as well as the gain in strength.

\section{Embankment stability assessment}

The stability of a 4, 5, 6, and $7 \mathrm{~m}$ high embankment was investigated by evaluating the factor of safety of the embankment on un-stabilized subgrade (USS) and on cement stabilized subgrade (CSS).

The factor of safety analysis usually can be performed with the classical limit equilibrium method or the finite element method, these two methods are capable of accurately predicating the factor of safety, Matthews et al. [25] however observed the finite element method produced better results in complex geometery problems. In the analysis of the highway embankment for this study, routine and accurate limit equilibrium Bishop method (1955) and advanced limit equilibrium Morgenstern-Price method (1965) was used in the determination of the safety factor for a circular slip surface. 
Stability analysis involving the limit equilibrium method (method of slices) relies on the assumptions that shear failure of soil due to overwhelming stress will occur along a preferred slip surface $[10,11]$. In determining this slip surface, a soil body above a chosen trial slip surface is divided into blocks or slices with planes of each block being vertical.

\section{Bishop's ordinary method}

In this approach, the slip surface is presumed to be a circle arc having a center of $O$ and radius of $r$, with the soil above the slip surface divided into vertical slices having a width $b$ and height $h$ from the centerline (Fig. 7). It assumes there are no inter-slice forces and relies on the satisfaction of moment equilibrium and vertical force of equilibrium [10, 11]. Limiting equilibrium is maintained when shearing forces along the slip surface is less than resisting forces on the failure plane. The factor of safety against shear failure along the slip surface is obtained from Eq. (1).

$$
F=\frac{\tau_{r}}{\tau_{a}}
$$

where $F=$ factor of safety against shear failure, $\tau_{r}=$ resisting force (shear strength being a function of phi $(\phi)$ and the cohesion (c)), $\tau_{a}=$ acting force (shear stress).

The forces acting on an individual slice is defined by $N=$ normal force at midpoint of slice base, $T=$ shearing resistance mobilized at the slice base, consequently, $x_{1}, x_{2}$ are inter-slice shear forces acting to the right and left respectively. The FoS is obtained by the Bishop's method using Eq. (2)

$$
\begin{aligned}
& F=\frac{1}{\sum w \sin \alpha} \sum\left\lfloor\left\{c^{\prime} b+W\left(1-r_{u}\right) \tan \phi^{\prime}\right\} \frac{\sec \alpha}{1+\left(\frac{\tan \alpha \tan \phi^{\prime}}{F}\right)}\right\rfloor \\
& r_{u}=\frac{u}{W / b}
\end{aligned}
$$

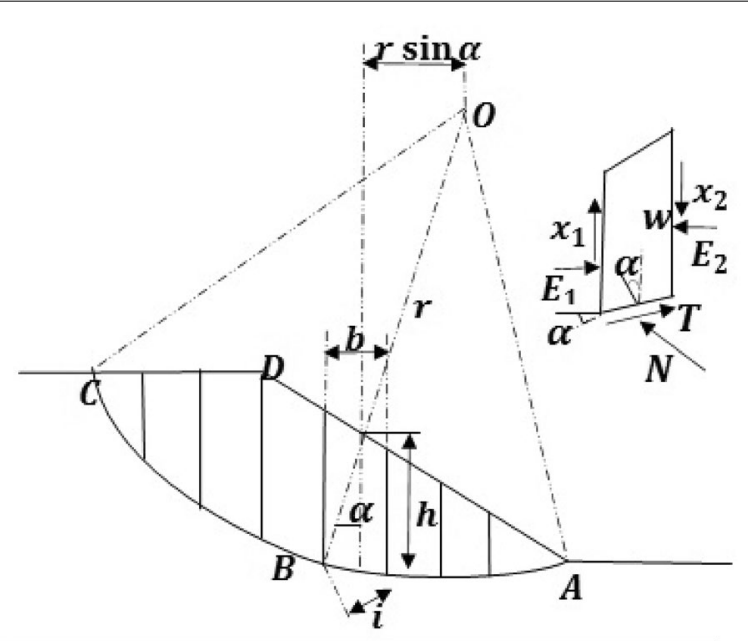

Fig. 7 The method of slices (after [10]) 
where $W=$ weight of slice, $b=$ width of slice, $c^{\prime}=$ effective cohesion, $\phi^{\prime}=$ effective friction angle, $r_{u}=$ pore pressure ratio, $u=$ pore pressure.

Ching and Fredlund [8] observed that for a saturated cohesive soil, the inability to quickly expel excess pore pressures generated by change incipient stress condition from embankment load will result in an undrained loading of the soil. This condition will result in the development of a deep-seated failure slip surface, which usually will extend from the crest of the embankment to beyond the embankment toe. Duncan et al. [13] therefore proposed total strees analysis for this condition, using soil total stress parameters of $\phi$ and $c$ in stability analysis.

\section{Morgenstern-Price method}

Morgenstern-Price (1965) developed a more rigorous method of determining the FoS using the method of slice. The method identifies and satisfies equation of moment equilibrium, vertical force of equilibrium and also of horizontal force of equilibrium [10]. For this method, Fig. 8 depicts the forces acting on a single slice, the forces include; normal effective force on the sides of a slice $(E)$, shear force on the side $(X)$, boundary water force on a side of the slice $\left(P_{w}\right)$, normal effective force at slice base $(d N)$, shear force on slice base $(d S)$, boundary water force on base, the total weight of the slice $(d W)$ and the function $y=z(x)$ representing the ground surface and a slip surface is represented by $y=y(x)$.

There is several commercial software with the capability of carrying out the complex iteration process used in determining the factor of safety using this method. This iteration process is used to determine the most critical slip surface. The FoS for the critical slip surface for both the Bishop's simplified method and the Morgenstern-Price method was obtained using the optimization process available in the GeoStructural analysis v18Slope Stability software.

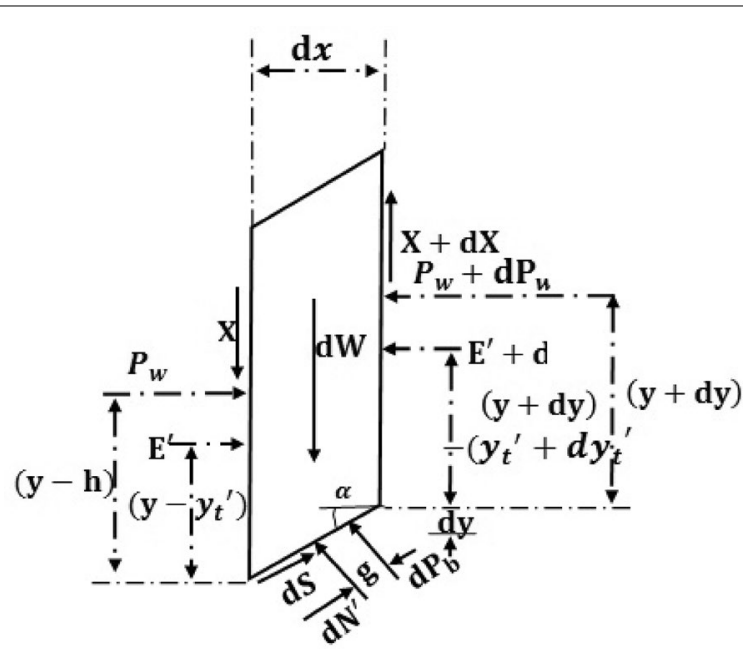

Fig. 8 The Morgenstern-Price method (after $[10,11])$ 

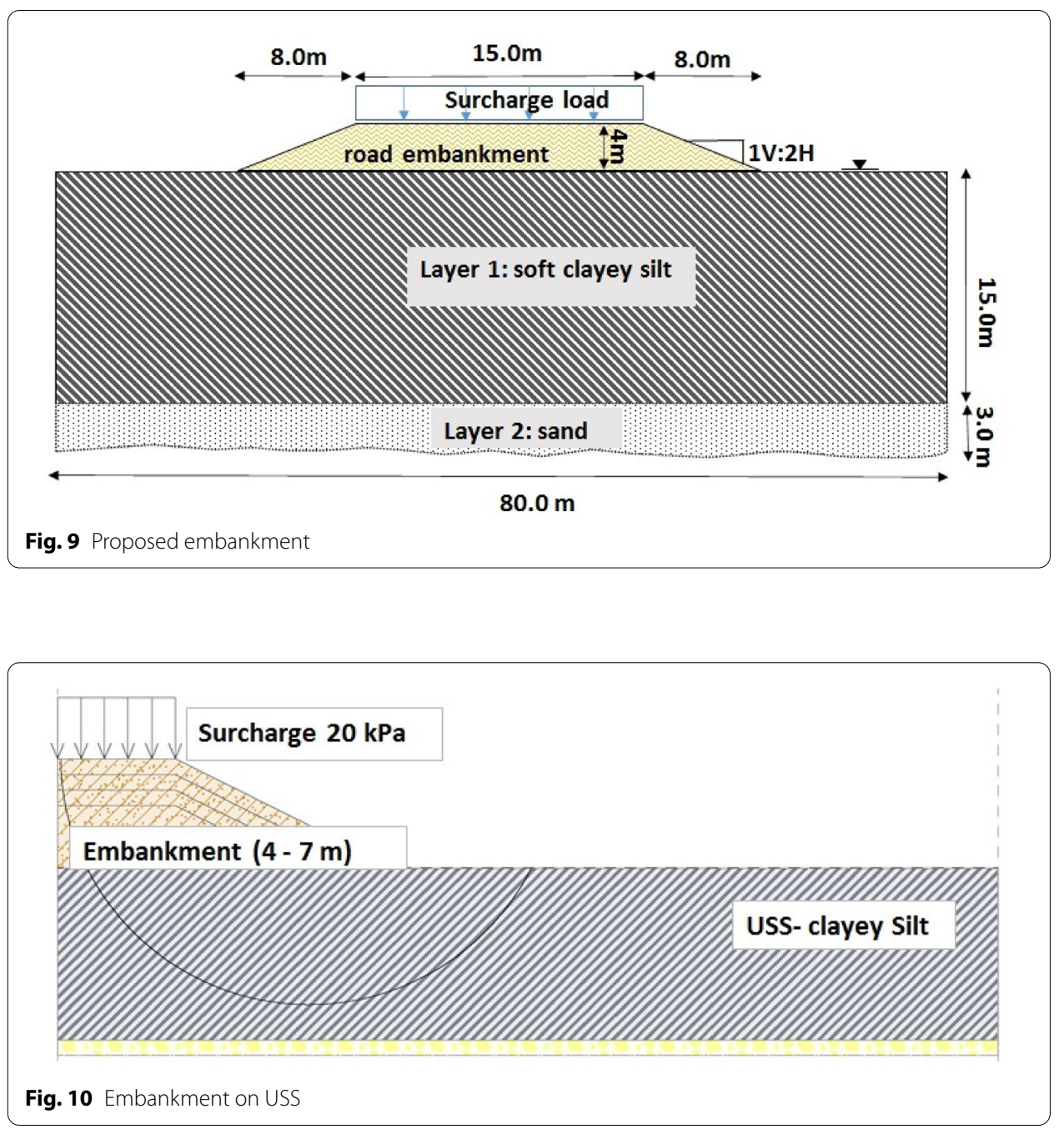

Stability analysis was carried out for a 1V:2H embankment (Fig. 9). The embankment height was varied from 4 to $7 \mathrm{~m}$ with $7 \mathrm{~m}$ being the most critical loading scenario. Stability was first performed for natural unstabilized soil for the various embankment heights (4 to $7 \mathrm{~m}$ ) (Fig. 10), then similarly for embankment on CSS. Mass stabilization depth was varied from 1 to $5 \mathrm{~m}$ (Fig. 11) and a traffic surcharge load of $20 \mathrm{kPa}$ was applied at the top of the embankment.

\section{Results and discussion}

The stratigraphy at the study location was observed to include a soft deposit being $11 \mathrm{~m}$ thick and an embankment fill. The soft soil was of medium to high plasticity having a fines content of 87 to $95 \%$ (Fig. 12) and high moisture content range of 49.2 to $108.6 \%$, the soil liquid limit $(L L)$ ranged from 63 to $149 \%$, plastic limit $(P L)$ ranged of 33 to $75 \%$ while PI ranged from 30 to $74 \%$, the soil plots below the ' $A$ ' Line on the Casagrande plasticity chart and is classified as high plasticity silt $(M H)$. AASHTO classifies the soil as A-7-6 soil and is unsuitable for construction purposes. The undrained shear strength $\mathrm{C} \mathrm{Cu}$ ) range of 10 to $17 \mathrm{kPa}$. The plasticity results fall short of the Nigerian Federal 

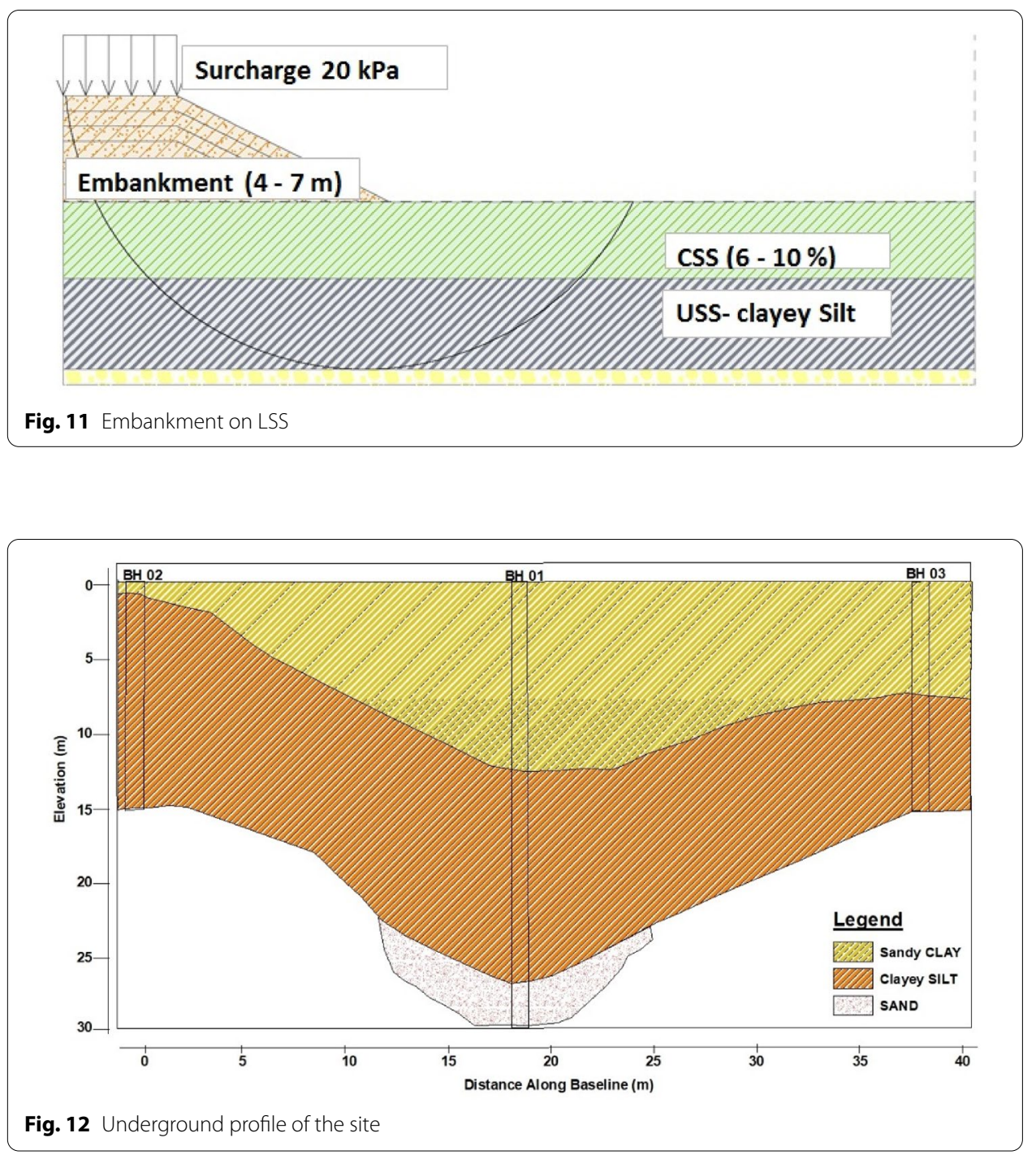

Ministry of Works and Housing (FMWH) [27] $L L$ requirements of $<30$ and PI requirement $<13$ for highway subgrade. Detailed results are summarized in Table 1.

Unconfined compressive strength (UCS), triaxial and CBR are effective ways of determining strength improvement of stabilized soil $[18,22]$. The strength of the cement stabilized subgrade was assessed from UCS after curing for 28 days, $\mathrm{Cu}$ of $154 \mathrm{kPa}$ was obtained for 6\% CSS and $208 \mathrm{kPa}$ for 10\% CSS (Fig. 13) indicating significant strength improvement when compared to the unstabilized samples (Fig. 14).

The stability analysis was carried out using parameters summarized in Table 2. From analysis of embankment on USS using the Bishop's method, FoS values of 1.2, 1.1, 0.97 and 0.88 were obtained for embankments having heights of 4, 5, 6, and $7 \mathrm{~m}$ respectively, the result compared favorably to those obtained from the MorgensternPrice's method which gave less conservative $F o S$ values of 1.33, 1.18, 1.06 and 0.97 for embankment heights of $4,5,6$, and $7 \mathrm{~m}$ respectively. The difference in values shows a 7 to $10 \%$ difference between the two methods showing similar agreements with Duncan [12] who observed that the differences in FoS between different limit equilibrium 
Table 1 Summarized results and geotechnical parameters for USS

\begin{tabular}{|c|c|c|c|c|}
\hline \multirow[t]{2}{*}{ Results } & \multirow{2}{*}{$\begin{array}{l}\text { Fill } \\
\text { Range }\end{array}$} & \multirow{2}{*}{$\begin{array}{l}\text { Subsoil } \\
\text { Range }\end{array}$} & \multicolumn{2}{|c|}{ Stabilized Soil } \\
\hline & & & $6 \%-C S S$ & $10 \%$-CSS \\
\hline \multicolumn{5}{|l|}{ Unit weight $\left(\mathrm{kN} / \mathrm{m}^{2}\right)$} \\
\hline Bulk & $19.8-20.6$ & $13.8-16.4$ & 14.1 & 14.4 \\
\hline Dry & $16.5-16.6$ & $6.8-11$ & 8.3 & 9.0 \\
\hline Moisture content; Mc (\%) & $19.2-24.9$ & $49.2-108.6$ & - & - \\
\hline Liquid limit; LL (\%) & $43-58$ & $63-149$ & - & - \\
\hline Plastic limits; PL (\%) & $22-27$ & $33-75$ & - & - \\
\hline Plasticity index; $I_{p}(\%)$ & $21-26$ & $30-74$ & - & - \\
\hline \multicolumn{5}{|l|}{ Grain size (\%) } \\
\hline Sand & $55-75$ & $5-13$ & - & - \\
\hline Fines (silt/clay) & $25-45$ & $87-95$ & - & - \\
\hline Undrained shear strength $\left(\mathrm{S}_{\mathrm{u}}\right) \mathrm{kPa}$ & $34-66$ & $10-17$ & 154 & 208 \\
\hline Friction angle $\left(^{\circ}\right)$ & $7-10$ & $1-3$ & - & - \\
\hline USCS & $\mathrm{CL}$ & MI-ME & - & - \\
\hline ASSHTO & $A-2-5$ & A-7-6 & - & - \\
\hline
\end{tabular}

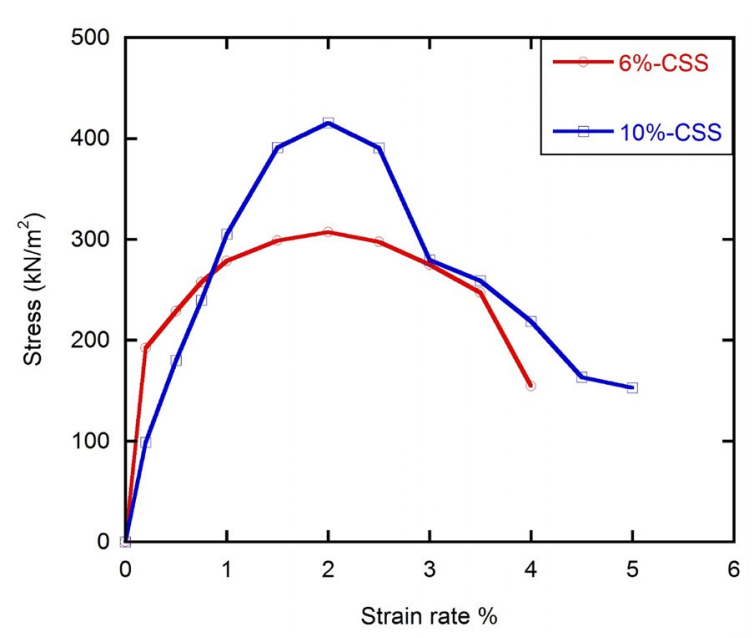

Fig. 13 Stress-strain curve for CSS

methods are usually less than $6 \%$. The $F o S$ for the various embankment heights constructed on USS did not satisfy stability FoS requirements of 1.3 on the short and 1.5 on the long term. The stability results on the embankment on unstabilized soils are indicative of the in ability of the soft soil to perform as a suitable subgrade for highway constructions, the stability analysis indicated a deep-seated slip surface within the foundation soil typical of undrained loading $[7,10]$. At the site, plastic failure and displacement of culvert and the presence of shear scars and heave at the site (Figs. 2, 3 ,4) validates the stability analysis on the USS. Ekeocha [14], Ekeocha and Akpokodje [15], Ilori [21] all in their study within the study location have identified and reported the poor strength subgrade to be responsible for extensive pavement failures observed within the study area. 


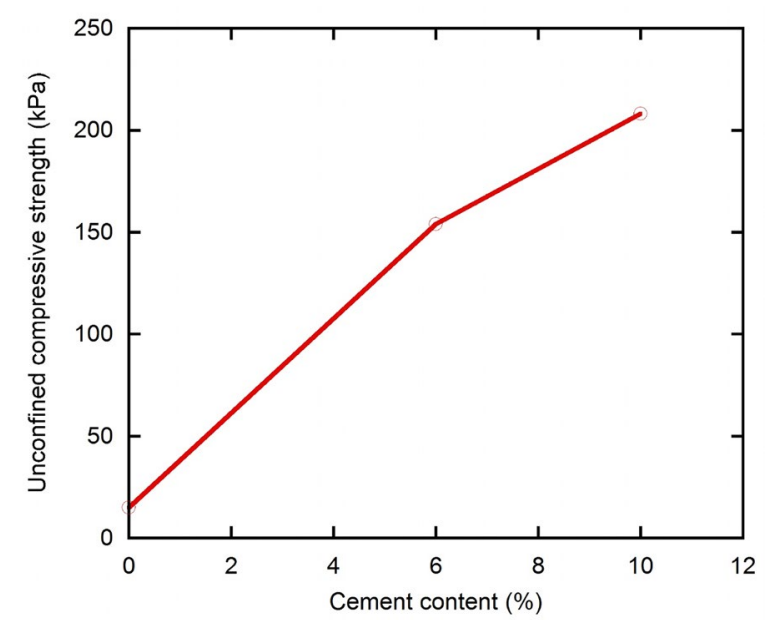

Fig. 14 Variation in soil Cu vs cement $\%$

Table 2 Summarized parameters for stability analysis

\begin{tabular}{llllllll}
\hline Parameter & Symbol & Fill & Sand & USS & CSS-6\% & CSS-10\% & Unit \\
\hline Binder & - & - & - & - & Cement & Cement & - \\
Composition & - & - & - & - & 6 & 10 & $\%$ \\
Dry unit weight & $\gamma_{\text {unsat }}$ & 17 & 18 & 8 & 8.3 & 9.0 & $\mathrm{kN} / \mathrm{m}^{3}$ \\
Bulk unit weight & $\gamma_{\text {sat }}$ & 20 & 18 & 15 & 14.1 & 14.4 & $\mathrm{kN} / \mathrm{m}^{3}$ \\
Undrained shear strength & $C_{u}$ & 50 & 1 & 15 & 154 & 208 & $\mathrm{kPa}$ \\
Friction angle & $\boldsymbol{\phi}$ & 9 & 35 & 3 & - & - & $\circ$ \\
\hline
\end{tabular}

Stability analysis which considered improvement of the weak soil with $6 \%$ and $10 \%$ cement produced several degrees of improvement to the FoS. The FoS values are presented in Table 3. Describing the results of the analysis using Bishop's method, the stability of the $4 \mathrm{~m}$ embankment increased by $48 \%$ from 1.2 to 1.77 after stabilizing the top $1 \mathrm{~m}$ of the weak soil with $6 \%$ cement. Subsequently, stability was further improved with increase in depth of mass stabilization, a $5 \mathrm{~m}$ stabilization depth improved the FoS value to 4.16 (Fig. 15), this signifies a $247 \%$ increment. This pattern of stability improvements was also observed for the different embankment height analyzed (5, 6 and $7 \mathrm{~m}$ ). Similar pattern of stability improvements with increase in stabilization depth was also observed for the different embankment height of 5, 6 and 7 m. 10\% cement stabilization produced an increase of $60 \%$ in the FoS value for a $4 \mathrm{~m}$ embankment when the top $1 \mathrm{~m}$ soft soil was stabilized. This increased the FoS value from 1.2 to 1.92 . Comparatively between the 6 and 10\% cement content, the best improvement was recorded for $10 \%$ cement stabilization with values of $F o S$ reaching as much as 5.22 (335\% increase) for $5 \mathrm{~m}$ depth of stabilization agreeing with Ekeocha and Akpokodje [15] and Ilori [21], on the linear increase in strength with increase in binder content. The analysis result further indicated that binder content alone was not the most significant factor in the improvement of the embankment stability. For a critical loading of $7 \mathrm{~m}$ embankment, $1 \mathrm{~m}$ stabilization was not sufficient to meet FoS 
Table 3 FoS for embankment

\begin{tabular}{|c|c|c|c|c|c|c|c|c|}
\hline \multirow{4}{*}{$\begin{array}{l}\text { Stabilization } \\
\text { depth }(m)\end{array}$} & \multicolumn{4}{|c|}{ Bishop's method } & \multicolumn{4}{|c|}{ Morgenstern-Price method } \\
\hline & \multicolumn{4}{|c|}{ Embankment height (m) } & \multicolumn{4}{|c|}{ Embankment height (m) } \\
\hline & 4 & 5 & 6 & 7 & 4 & 5 & 6 & 7 \\
\hline & \multicolumn{4}{|l|}{ FoS } & \multicolumn{4}{|l|}{ FoS } \\
\hline \multicolumn{9}{|l|}{ USS } \\
\hline- & 1.2 & 1.1 & 0.97 & 0.88 & 1.33 & 1.18 & 1.06 & 0.97 \\
\hline \multicolumn{9}{|l|}{$6 \%$-CSS } \\
\hline 1 & 1.77 & 1.49 & 1.29 & 1.16 & 1.84 & 1.55 & 1.36 & 1.22 \\
\hline 2 & 2.34 & 1.95 & 1.68 & 1.52 & 2.38 & 2.02 & 1.73 & 1.52 \\
\hline 3 & 2.93 & 2.44 & 2.08 & 1.88 & 2.96 & 2.45 & 2.10 & 1.89 \\
\hline 4 & 3.53 & 2.95 & 2.52 & 2.24 & 3.52 & 2.93 & 2.52 & 2.20 \\
\hline 5 & 4.16 & 3.47 & 2.95 & 2.61 & 4.14 & 3.44 & 2.94 & 2.59 \\
\hline \multicolumn{9}{|l|}{$10 \%$-CSS } \\
\hline 1 & 1.92 & 1.61 & 1.40 & 1.26 & 1.98 & 1.67 & 1.46 & 1.31 \\
\hline 2 & 2.71 & 2.25 & 1.93 & 1.76 & 2.75 & 2.31 & 1.98 & 1.73 \\
\hline 3 & 3.53 & 2.92 & 2.48 & 2.25 & 3.55 & 2.91 & 2.49 & 2.24 \\
\hline 4 & 4.35 & 3.58 & 3.09 & 2.74 & 4.33 & 3.58 & 3.08 & 2.67 \\
\hline 5 & 5.22 & 4.33 & 3.69 & 3.25 & 5.19 & 4.30 & 3.66 & 3.23 \\
\hline
\end{tabular}

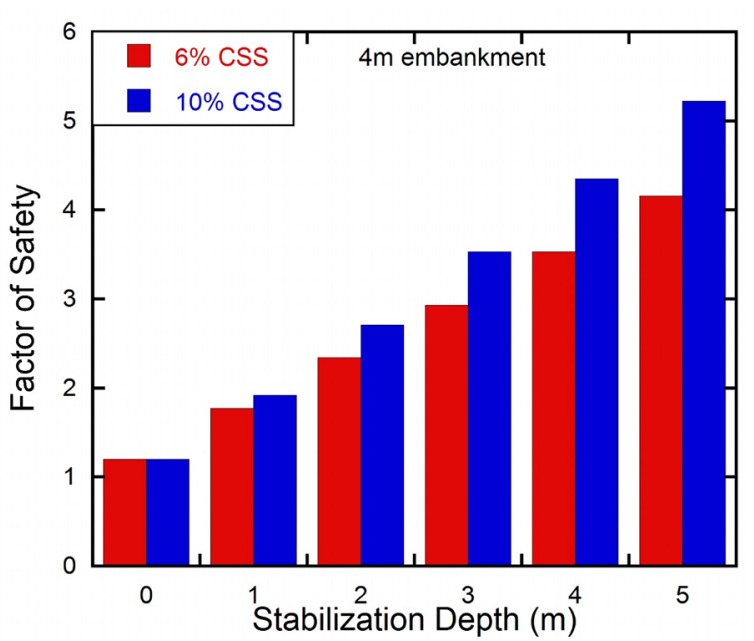

Fig. 15 FoS for $4 \mathrm{~m}$ embankment on CSS

requirement. The requirement was however satisfied with the increase in the mass stabilization depth to above $2 \mathrm{~m}$ (Fig. 16) agreeing with Saadeldin et al. [35] on the role of mass stabilization depth on stability of embankment regardless of the binder content and quantity. A relationship was observed to exist between the strength of stabilized soil, mass of stabilized depth and the FoS (Figs. 17 and 18). In other words, the embankment stability will improve if more mass or depth of stabilized material is achieved under the embankment, the strength improvement of course was primarily gained from the increase in the strength of weak soil due to the addition of Portland 


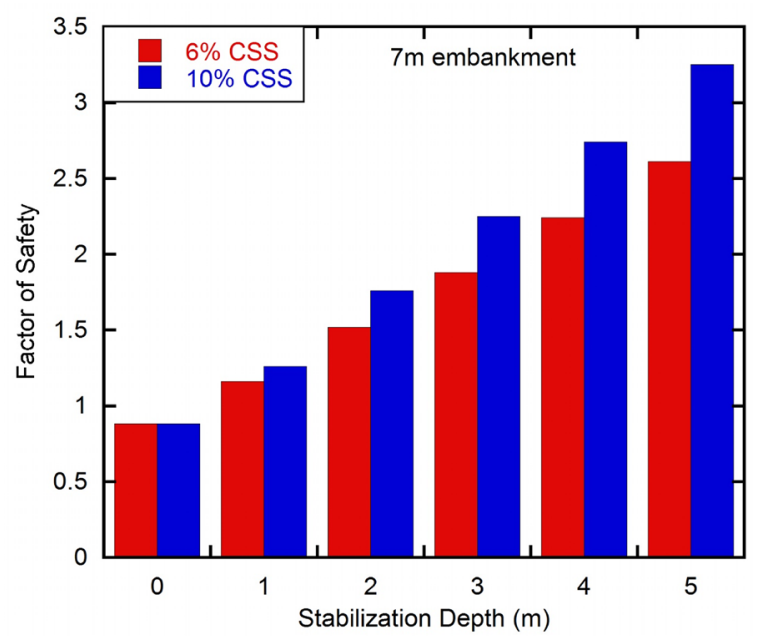

Fig. 16 FoS for 7 m embankment on CSS

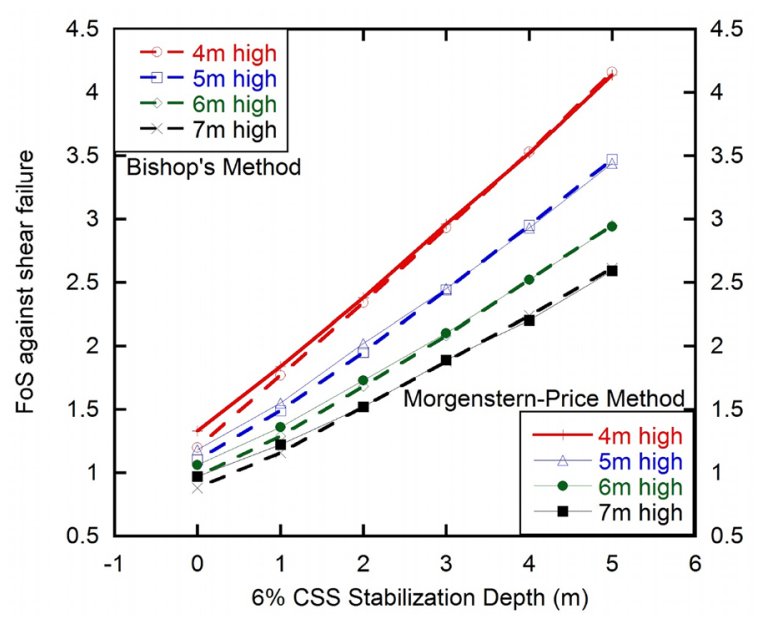

Fig. 17 FoS vs stabilization depth vs embankment height on 6\%CSS

cement. For a stability FoS requirement of 1.5, an embankment of 4, 5, 6 and $7 \mathrm{~m}$ can be safely constructed after improving 2 to $3 \mathrm{~m}$ of the weak soil with $6 \%$ cement, where critical conditions require higher $F o S$ as stability requirement, the embankments of 4 to $7 \mathrm{~m}$ high can be constructed with deeper soil stabilization up to a maximum of $5 \mathrm{~m}$ or by increasing the cement to soil ratio to $10 \%$. The best improvement which was encountered for cement content of $10 \%$ and stabilization depth of $5 \mathrm{~m}$ cannot however be regarded as the best cost-effective solution when cost of improvement and construction is considered. 


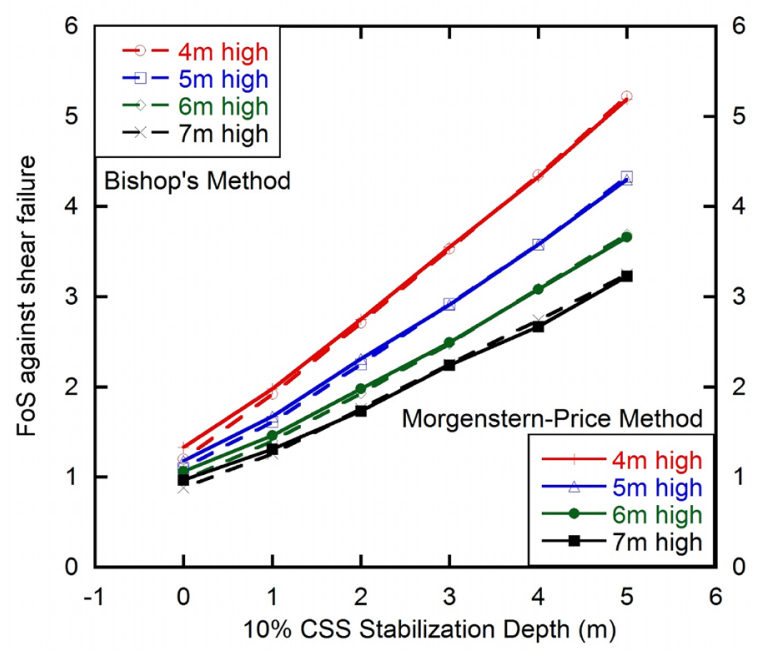

Fig. 18 FoS vs stabilization depth vs embankment height on 10\%CSS

\section{Conclusions}

1. Shear strength of weak soils from south east of Nigeria was improved with Portland cement to achieve safety during embankment construction or for other construction purposes. Soil strength was observed to improve with increase in cement content, this defines a linear relationship existing between the cement content and strength of improved soil.

2. Mass stabilization of weak soil produced higher FoS. The FoS increased with increase in depth of stabilization and increase in cement content. The increase in both cement content and depth of stabilization provided much better improvement than increase of either cement content or stabilization depth.

\section{Funding}

Funding for the success of this research was made available by Benchmark Engineers and Consultants Limited.

Availability of data and materials

The data that support the findings of this study are available from the corresponding author, upon reasonable request.

Code availability

Not applicable.

\section{Declarations}

\section{Competing interests}

The authors declare that they have no competing interests.

\section{Author details}

${ }^{1}$ Department of Geology, Faculty of Science, University of Port Harcourt, Choba, Rivers State, Nigeria. ${ }^{2}$ Department of Geology, College of Environmental Sciences, Gregory University Uturu, Uturu, Abia State, Nigeria.

Received: 28 March 2018 Accepted: 9 August 2021

Published online: 04 January 2022 


\section{References}

1. Abdulfatai IA, Okunlola IA, Akande WG, Momoh LO, Ibrahim KO (2014) Review of gully erosion in Nigeria: causes, impacts and possible solutions. J Geosci Geomat 2(3):125-129

2. Adeleye DR, Fayose EA (1978) Stratigraphy of the type section of Awi Formation, Odukpani area, Southeastern Nigeria. J Mining Geol 15:35-37

3. Adesunloye MO (1987) Investigating the problem soils of Nigeria. In: 9th regional conference for Africa on soi mechanics and foundation engineering, Vol 1, A.A Balkema/Rotterdam/Boston. pp 103-112

4. Al-Tabbaa A, Perera AS (2005) State of practice report, UK stabilization/solidification treatment and remediation, part I: binders and technologies- basic principles. In: Proceedings of the international conference on stabilization/solidification treatment, Cambridge, Taylor and Francis, pp 365-385

5. Balasubramaniam AS, Cai H, Zhu D, Surarak C, Oh EY (2010) Settlements of embankments in soft soils. Southeast Asian Geotech Soc Geotech Eng J 41(2):1-19

6. Bolarinwa A, Ola SA (2016) Review of the major problem soils in Nigeria. J Eng Technol 1:20-25

7. Chen FH (2000) Soil engineering: testing, design and remediation. CRC Press LLC, Florida

8. Ching RK, Fredlund DG (1984) Quantitative comparison of limit equilibrium methods of slices. In: Proceedings of the fourth international symposium on landslides, Toronto, Canada. pp 373-379

9. Chukwueze HO (1991) Geotechnical and geological properties of tropical soils. In: 9th regional conference for Africa on soil mechanics and foundation engineering, Vol 2, A.A Balkema/Rotterdam. pp 731-735

10. Craig RF (2004) Soil mechanics, 7th edn. Taylor and Francis Group, London

11. Craig RF (2006) Soil mechanics, 8th edn. E and F Spon, New York

12. Duncan JM (1996) State of the art: limit equilibrium and finite-element analysis of slopes. J Geotech Eng 577-596

13. Duncan JM, Buchignani AL, Wet MD (1987) An engineering manual for slope stability studies. Virginia Tech Center for Geotechnical Practice and Research, Blacksburg, VA

14. Ekeocha NE (2014) Geotechnical implications of using shale as subgrade material. Asian Trans Basic Appl Sci 4(2):1-5

15. Ekeocha NE, Akpokodje EG (2014) Cement stabilization characteristics of shale subgrade of parts of the Lower Benue Trough, Southeastern Nigeria. Int J Sci Technol 3(1):78-84

16. Ekwueme BN, Nyong EE, Petter SW (1995) Cretaceous sediments in the calabar flank. In: Geological excursion guidebook to Oban Massif, Calabar Flank and Mamfe Embayment, Southeastern Nigeria, Calabar, Ford Publishers LTD

17. Etim RK, Ebermu AO, Osinubi KJ (2017) Stabilization of black cotton soil with lime and iron ore tailings admixture. Transport Geotech 10:85-95

18. Euro SoilStab (2002) Development of design and construction methods to stabilize soft organic soils: design guide soft soil stabilisation. European Commission, Industrial and Materials technologies Programme, Bryssel

19. Gidigasu MD (1976) Laterite soil engineering. Elsevier, Amsterdam

20. Huat BB (1998) An investigation of an embankment failure in soft clay. In: Fourth international conference on case histories in geotechnical engineering, St. Louis, Missouri. pp 430-433

21. Ilori AO (2016) Occurance of shale soils along the Calabar-Itu Highway, Southeastern Nigeria and their implication for subgrade construction. Springer Plus 5(209):1-13

22. Ingles OG, Metcalf JB (1972) Soil stabilization principles and practice. Butterworths, Australia

23. MacLaren DC, White MA (2003) Cement: its chemistry and properties. J Chem Educ 8(6):623

24. Makusa GP (2012) State of the art review-soil stabilization methods and materials in engineering practice. Department of Civil, Environmental and Natural Resources Engineering, University of Technology Luleå, Luleå

25. Matthews C, Farook Z, Helm P (2014) Slope stability analysis- limit equilibrium or finite element method. Ground Eng 48:22-28

26. Mitchell JM, Jardine FM (2002) A guide to ground treatment. Construction Industry Research and Information Association (CIRIA), London

27. Nigerian Federal Ministry of Works (FMWH) (1997) General specification for roads and bridge works. Federal Government of Nigeria, Abuja

28. Obaje NG (2009) Geology and mineral resources of Nigeria. Springer, Berlin, Heidelberg

29. Ofudu O, Tse AC, Akpokodje E (2016) Stabilization of dredged spoils for pavement construction in the Niger Delta, Nigeria. Glob J Geol Sci 14:87

30. Ola SA (1987) Laboratory testing and geotechnical characterization of black cotton soil and expansive shales in Nigeria. In: 9th regional conference for africa on soil mechanics and foundation engineering, Vol 1, A.A Balkema/Rotterdam/Boston. pp 991-995

31. Omotosho O, Eze-Uzomaka OJ (2008) Optimal stabilization of deltaic laterite. J S Afr Inst Civil Eng 50:10-17

32. Onyelowe KC, Okoafor FO (2012) Geochemistry of soil stabilization. Asian Res Publ Netw J Earth Sci 1:32-35

33. Petters SW, Nyong EE, Akpan EB, Essien NU (1995) Lithostratigraphic revision for the Calabar Flank, Southeast Nigeria. In: Proceedings of the 31st annivesary conference of Nigeria mining and geosciences society, Calabar

34. Reijers TJ, Petters SW (1987) Depositional environment and diagenesis of Albian carbonates in Calabar Flank, Southeast Nigeria. J Pet Geol 10:283-294

35. Saadeldin R, Salem MA, Lotfi HA (2011) Experimental investigation and finite element analysis of highway embankment on soft clay. Electron J Geotech Eng 17:403-417

36. Salem TN, El-Kady MS, Abd-Elbaset AM (2013) Soft clay treatment using portland cement and hydrated lime. Egypt Int J Eng Sci Technol 19:267-274

37. Sherwood PT (1995) Soil stabilization with cement and lime: state of the art review. Transport Research Laboratory, London, p 153

38. State of Queensland (Department of Transport and Main Roads) (2015) Geotechnical design manual-minimum requirements. Transport and Main Roads, Queensland

\section{Publisher's Note}

Springer Nature remains neutral with regard to jurisdictional claims in published maps and institutional affiliations. 